\title{
Strategic planning and remuneration
}

\author{
G.S. Andrews
}

Graduate School of Business Administration, University of the Witwatersrand, Johannesburg

\begin{abstract}
Management thought, practice and process have changed dramatically over the recent past and we need new ways to think about how business performs and how to measure the managers who run our business operations. With rapidly changing markets, technologies, customers, suppliers and consumers, more and more emphasis is being placed on thinking strategically and on how to position the business for the future. Unfortunately many firms are still grappling with the concept of strategy and do not fully understand the concept of strategic management. As a result, many managers are being encouraged by the reward and compensation system to act in their own interests and not in the company's interests. Poorly designed measurement and compensation systems tend to reward short-term thinking and do not recognize the value of strategic compensation systems. Managers must be made partners in a firm's success by linking compensation to the strategic variables of success.

S. Afr. J. Bus. Mgmt. 1986, 17: 13-16
\end{abstract}

Bestuursdenke, -praktyke en -prosesse het in die jongste verlede dramaties verander. Ons moet nou besin oor nuwe benaderings oor hoe besighede funksioneer en oor hoe om die bestuurders wat hierdie besighede bedryf te evalueer. Met die snelveranderende markte, tegnologieë, klante, verskaffers en verbruikers word al meer aandag gewy aan die strategie en die posisionering van die besigheid met die oog op die toekoms. Menige firma is ongelukkig nog steeds besig om te worstel met die begrip strategie en verstaan die begrip strategiese bestuur nog nie heeltemal nie. Die gevolg hiervan is dat baie bestuurders deur die beloning- en vergoedingstelsels aangespoor word om in hul eie eerder as die maatskappy se belang op te tree. Swakontwerpte evaluering- en vergoedingstelsels neig om korttermyndenke te beloon en erken nie die waarde van 'n strategiese vergoedingstelsel nie. Bestuurders behoort vennote gemaak te word in die firma se sukses deur vergoeding te verbind aan die strategiese veranderlikes van sukses.

S.-Afr. Tydskr. Bedryfsi. 1986, 17: 13-16

Presented at the P.E. Corporate Services Executive Remuneration Conference, Johannesburg, 19 February 1985

\section{G.S. Andrews}

Graduate School of Business Administration, University of the Witwatersrand, P.O. Box 31170, Braamfontein, 2017 Republic of South Africa

\section{Introduction}

The game has changed and will continue to change. Today every manager recognizes that management thought, practice and process have changed dramatically in recent years. We know that there have been, and are occurring today, massive conceptual changes in the ways that management theorists and practitioners think about business life. One of the new words that seems to have been introduced into almost every facet of business is that of 'strategy'. Almost every area of today's firm seems to be undergoing some form of strategic change. Every functional and operational area of the firm refers to 'its strategy' - for example, managers refer to sales strategy, marketing strategy, customer strategy, competitor strategy, advertising strategy, promotional strategy, cash strategy, investinent strategy, production strategy, manufacturing strategy, pricing strategy, buying strategy, and many other 'strategies'.

The word strategy is used in a very loose and generalized way. When we refer to 'corporate strategy' we refer to the process that management uses to enable it to manage an orderly transition into the future. Strategic planning attempts to relate the organization to its environment in the optimum fashion so as to achieve specified goals and objectives. However, every organization and every individual will have a different definition of strategic planning. Here are a few such definitions:

- Strategic planning is a method of developing new skills necessary for effectively managing tomorrow's business

- Strategic planning is a method for allocating the company's scarce resources in support of tommorow's business

- Strategic planning is the method for selecting the optimum path from today's business to tommorrow's business

- Strategic planning is the method for dealing with external complexity in the company's markets

- Strategic planning is the method for dealing with internal complexity created by changes in the environment and the need to have many sub-units within the organization.

Obviously strategic planning means different things to different people but the common thread that runs through most definitions is that of an orientation towards managing complexity, change and positioning in the future. The concept of strategic planning and policy also encompasses the responsibility and functions of senior management as well as decisionmaking with regard to, and the implementation of programmes that determine and shape the organization's future. Strategic planning has to do with the choice of purposes, the moulding of organizational identity and character, the continuous definition of what has to be performed, and the channelling of all 
the resources available to the attainment of goals in a hostile and competitive environment. It is not easy!

\section{Corporate success defined}

Some companies are, despite all these difficulties, extremely successful. Others, managed by executives and staffed by individuals who, on the face of it, are as well-qualified and experienced as those managing the successful firms, fail abysmally. Perhaps it will be useful at this point to discuss the concept of corporate success briefly. I believe that the market is the best long-term judge of corporate vitality and performance. I stress 'long-term' because there are many examples of companies that were judged to be outstanding at a particular point in time and which history and hindsight have revealed to have been strategically impoverished. My approach is that suggested by the theory of corporate finance, namely that the objective of management should be to earn a rate of return on the capital entrusted to it by shareholders, that equals or exceeds the cost of that capital. Many executives, because they do not fully understand the underlying causes of value, often mistakenly pursue growth as a major strategic objective. The mania for size through asset and investment expansion evidenced in many firms bears testimony to that lack of understanding. Growth, without adequate profitability and suitable corporate positioning, can actually detract from value. My approach is perhaps best illustrated by Figure 1 which relates risk and return.

In Figure 1, a firm with a systematic risk of ' $A$ ' is shown to require a return of $R 1$ whereas firm $B$, with a higher risk is required to produce a commensurately higher return of $R 2$. If the management is unable to produce these returns then share price will decline to the point where the marginal investor will earn the appropriate return. In my opinion this is a fundamental truth in business. Many executives will 'agree' with the statement that management should produce returns greater than the cost of capital. Yet if you ask them to prove this or how to calculate the 'cost of capital' you will find that most are unable to do so. The fact that most South African companies quoted on the Johannesburg Stock Exchange stand at a discount on their historical net asset value is indicative of the fact that either firms do not know what return is required of them and have not invested, or they have not been managed in a way that preserves and builds shareholder value.

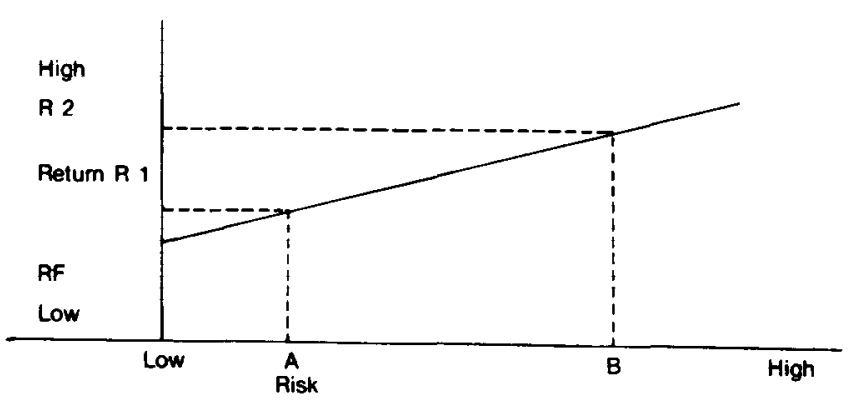

Figure 1 Risk and return and corporate objectives

The overriding measure of management's performance is therefore the market price $(\mathrm{P})$ to book value $(\mathrm{B})$ ratio, commonly known as the $\mathrm{P} / \mathrm{B}$ ratio. Good companies have high $\mathrm{P} / \mathrm{B}$ ratios - that is, ratios greater than 1,0 . Conversely, poor companies have $\mathrm{P} / \mathrm{B}$ ratios of less than 1,0 . We can relate growth to actual required returns and the price/book value ratio is illustrated in Figure 2.

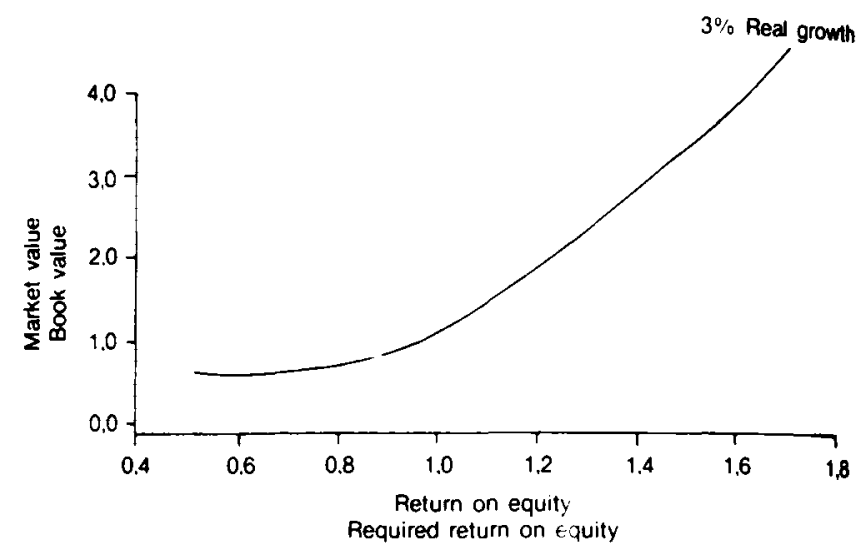

Figure 2 The relationship between actual/required returns, growth and the price/book ratio

Ultimately, the total corporation and its components, commonly known as its 'Strategic Business Units' (SBU's) can be shown to relate to the $\mathrm{P} / \mathrm{B}$ ratio. An example of how an inappropriate strategy can affect the $P / B$ ratio is provided in a later section of this article.

\section{What drives performance?}

Ask the average manager - 'What are the key determinants of business success?' - and you will be given a complete list of vague and unmeasurable factors. Yet we know a great deal about these determinants of success. The research findings that I will show you have been developed from a research study started by General Electric in the early 1960s. The research shows quite clearly that relative share of market, relative product quality, and a whole range of other factors are very important in determining SBU performance. We are focusing on return on investment (ROI) in this case (where $\mathrm{ROI}=\mathrm{EBIT} /$ capital employed). The values shown are fouryear averages for the very large number of SBU's which constitute the PIMS data base.

\section{How 'excellence' is achieved and lost}

The point of this discussion is that companies can be divided into a number of categories, based on their SBU and overall corporate performance. A broad classification that suggest itself is that of:

- strategic excellence and

- operating excellence

The findings, based on predetermined criteria and using the PIMS data base, indicate that companies earn the following ROI's when divided in the $3 \times 3$ matrix shown in Table 1 .

The successful company is obviously able to obtain both strategic and operating excellence and maintain this position. Unfortunately, however, the evidence (again obtained from

Table 1 Four-year ROI performance of SBU's classified on strategic and operating 'excellence'

\begin{tabular}{lrcc}
\hline & \multicolumn{3}{c}{ Operating effectiveness } \\
\cline { 3 - 4 } ROI $^{\mathbf{a}}$ & Negative & Average & Positive \\
\hline Strategic positioning & & 5 & 22 \\
$\quad$ Low & -14 & 20 & 42 \\
Average & 2 & 38 & 66 \\
Strong & 16 & 38 \\
\hline
\end{tabular}

${ }^{\text {a }} \mathrm{ROI}$ is defined as earnings before interest and tax as a percentage of capital employed. The values shown are four-year averages (Nowill). 
the PIMS research) shows that firms find it extremely difficult to maintain or sustain this level of performance. The findings show that the poor firms improve over time whereas the outstanding fall back.

\section{A strategic view of profitability, growth and manage- ment performance}

Returns are related to risk and if strategic goals are to be met then management must have a complete understanding of how these factors are linked. Assume a company with R1 000 invested share capital with a risk-adjusted required rate of return (RROR) of $10 \%$. If the net operating profit after tax (NOPAT) is $R 100$, the total value of the firm's shares or market capitalization will be $100 / 0,1=R 1000$. If 1000 shares are in issue, the market price per share will be $100 \mathrm{c}$ and the book value will also be $100 \mathrm{c}$ per share. Thus $\mathrm{P} / \mathrm{B}=100 / 100=1: 1$.

If the firm can increase NOPAT to R110, while keeping risk constant and hence the RROR at $10 \%$, the share price will rise to $110 \mathrm{c}$ and the $\mathrm{P} / \mathrm{B}$ to $1,1: 1$. The share price will rise as investors realize that this firm can produce economic returns (hence the emphasis on NOPAT-determined return measures and not accounting returns) above the cost of capital (RROR) and will bid up the share price to that price where the marginal investor will earn a return of $10 \%$.

What happens if management believes that 'growth' is required and undertakes an investment of R200 financed by equity alone, that will increase EPS and assets? The result will be as follows:

\section{Existing capital (1 000 shares issued)}

2. Required rate of return (RROR)

3. Net operating profit after tax (NOPAT)

\section{Share price}

5. Market capitalization (R100/0,1)

6. Earnings per share (EPS)

7. Price to book ratio $(\mathrm{P} / \mathrm{B})$

8. New investment

9. Return on new investment

10. NOPAT on new investment

11. Total investment (Line $1+$ Line 8 )

12. Total NOPAT (Line $3+$ Line 10)

13. New return achieved $(116 / 1200)$

14. New market capitalization

(R 116/0,1)

15. New earnings per share

(Line $12 \div 1000$ )

16. New share price (Line $14 \div 1000$ shares)

17. New net asset value per share (Line $11 \div 1000$ shares)

18. EPS growth rate (Line $15 \div$ Line 6 )

19. New price to book ratio

$$
\text { (Line } 16 \div 17 \text { ) }
$$

Clearly, despite the fact the EPS have grown by $16 \%$, the price/book ratio has declined. Most companies would agree that because EPS and earnings have increased by $16 \%$, this is 'good' performance and management should be remunerated because the growth of earnings exceeds the $10 \%$ required return. Actually, management has not met shareholder and market expectations and should not be compensated. The firm may have grown but that growth is 'unprofitable' and has detracted from company value.

Obviously, this is a fairly simple example, but the principle is important and, I believe, relevant. Although we are only examining the firm for a single year, the analysis of performance should rather be measured over a reasonable period of time. Management must be evaluated against what 'they say they are going to do' over this period of time - in other words, their performance should be evaluated against the backdrop of a strategic plan - not a budget. Unfortunately, most firms and managers are unable to make the distinction between a strategic plan and a budget.

\section{Linking management compensation and strategic per- formance}

The compensation programme, if it is to recognize the strategic component of management performance, must measure strategic contribution rather than the operational contribution made by management alone. Top management are supposed to manage the long-term strategic situation - yet most compensation systems are geared toward the short-term operational situation. In addition, compensation systems are most often based on enormous and/or strategically misleading criteria such as growth. One of the quickest ways to grow a firm is by acquisition. South Africa is no exception to this trend toward large firms with unrelated business units. Yet we know from studies carried out in many countries, including South Africa, that unrelated businesses are worth less than if they were stand-alone units. This is known as the 'conglomerate discount'. I am certain that a great deal of the conglomerate diversification that we see is due primarily to the rewards (both financial and psychological) of running a 'big business'. Apparently it does not matter how well you run that business; as long as it is big you are regarded as being an industry spokesman and receive many accolades from the press.

This trend towards large groupings of unrelated business units introduces a further layer of complexity, particularly from a compensation point of view. The large 'conglomerates' will contain many SBU's which may, or may not, be clustered into quoted, holding companies. This means that many SBU managers are managing 'distinct' businesses but do not have the market place against which to measure performance. Consequently, an objective performance measure such as that provided by PIMS is required. However, despite the fact that many business units are 'self standing', they may also be able to play roles, which when coordinated, can add to total corporate performance. The highly focused SBU can contribute to corporate value and performance but groups of SBU's may be able to orchestrate their activities to enhance and reinforce competitive advantage. The firm may need to coordinate the goals and strategies of related and/or unrelated SBU's so that offensive and defensive activities are more effective and to identify new industries to enter based on concerted, integrated programmes.

A further complication exists when examining a firm with multiple SBU's: Almost all firms will have SBU's which fall into differing, strategic environments. Hence SBU strategies will range from growth of market share to harvest of share, to seeking competitive advantage through higher relative product quality, to those seeking advantage through drives to become the industry's lowest cost producer. Clearly, strategic compensation systems should take account of these differences. The well-known market attractiveness/competitive position matrix illustrated in Figure 3, gives an example of different SBU's positioned in the matrix.

Certain SBU's are seen to be located in the 'low overall attractiveness' area whereas others are located in 'medium' and 'high attractiveness' zones. Proponents of this portfolio view argue that each SBU should follow a 'growth' strategy based on the matrix - SBU's in highly attractive markets that possess strong business positions should pursue a growth strategy. Given such a portfolio, management should structure 


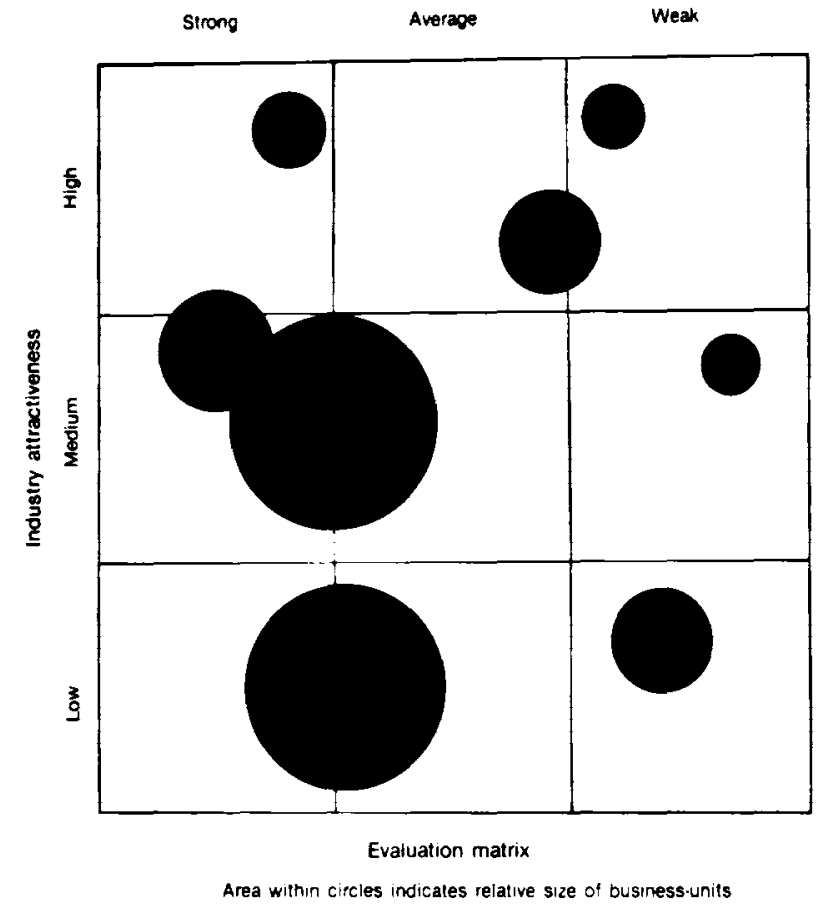

Figure 3 A corporate portfolio of strategic business units

a compensation plan that recognizes the different factors that are required of a particular strategy. Table 2 illustrates one possible plan which weights the relative importance of the factors.

In this example, managers of the high-growth SBU's are highly rewarded if they grow market share and invest heavily in 'strategic funds'. (Strategic funds are those funds that are used to enhance and develop agreed-upon strategic thrusts.) Managers of low-growth SBU's are not rewarded for market share growth. Rather, they are encouraged to generate cash managed for high return and not to deploy 'strategic funds'.

\section{Conclusion}

Every business is different. The very fact that different strategic plans are drawn up for different divisions and SBU's within a company bears testimony to this fact. Yet many firms have not taken the trouble to build reward/compensation systems that ensure that their plans are implemented. Instead, we tend to manage by the 'averages' and treat all SBU's in the same way. Top managers, if they believe that they can
Table 2 Weighted strategic factors and SBU strategy

\begin{tabular}{llc}
\hline SBU category & Factor & Weight (\%) \\
\hline High growth & Return on investment & 10 \\
& Cash flow & 0 \\
& Strategic funds deployment & 40 \\
& Share of market growth & 50 \\
& & 100 \\
Medium growth & \multicolumn{1}{c}{ Return on investment } & 25 \\
& Cash flow & 25 \\
& Strategic funds development & 30 \\
& Share of market growth & 20 \\
& & 100 \\
Low growth & $=$ \\
& Return on investment & 40 \\
& Cash flow & 60 \\
& Strategic funds development & 0 \\
& Share of market growth & 100 \\
& & $=$ \\
\hline
\end{tabular}

'make the difference' should take home relatively low base payments and very high incentive payments if they produce the strategic results. Too often, compensation systems are designed to avoid tax rather than to develop strategic advantage. They then become separated from the overall context of the organization. These systems must influence behaviour - but too often reinforce the wrong behaviour.

Strategic change is imperative if the organization is to survive and this requires change; the compensation system must have more 'fit' with the future state and less with the traditional/present state. Consequently, the well-designed, strategically-orientated compensation system will be uncomfortable; it will hurt in places, indeed must hurt in places if it is to push and pull the business into the future. We must remember that people never do what is expected of them they do what is inspected. If you expect your management team to create the future you had better inspect the appropriate variables and then reward them - handsomely.

\section{References}

Nowill, P. 'The Senior Executive Tightwire Act: Balancing the Portfolio of Businesses', PIMS letter, The Strategic Planning Institute, Cambridge, Massachusetts. 